\title{
New P16 Expression Criteria Predict Lymph Node Metastasis in Patients With Non-small Cell Lung Cancer
}

\author{
HYO JUNG AN ${ }^{1}$, HYUN MIN KOH ${ }^{1}$ and DAE HYUN SONG ${ }^{1,2,3}$ \\ ${ }^{1}$ Department of Pathology, Gyeongsang National University Changwon Hospital, Changwon, Republic of Korea; \\ ${ }^{2}$ Gyeongsang National University School of Medicine, Jinju, Republic of Korea; \\ ${ }^{3}$ Gyeongsang Institute of Health Science, Jinju, Republic of Korea
}

\begin{abstract}
Background: There have been many attempts to predict the prognosis of lung cancer based on the expression patterns of P16 protein, but with limited success. The Eighth American Joint Committee on Cancer (AJCC) for head and neck cancer recently developed new criteria for evaluating P16 expression. Here, we applied these new criteria to evaluate the prognosis of non-small cell lung cancer (NSCLC). Materials and Methods: A total of 148 patients who had undergone surgery for NSCLC were enrolled in the study. P16 protein expression patterns from NSCLC tissue microarray samples were examined by immunohistochemical analysis. The Eighth AJCC head and neck cancer staging criteria were used to evaluate positive P16 expression (moderate/strong nuclear expression intensity and distribution $>75 \%$ cells) in NSCLC. The relationship between P16 expression and clinicopathological factors were evaluated and survival analysis was included. Results: Negative P16 expression was significantly associated with NSCLC with lymph node metastasis ( $p=0.025)$. In addition, patients with NSCLC with negative P16 expression demonstrated poor disease-free and disease-specific survival in multivariate analysis. The Kaplan-Meier survival curve confirmed that negative P16 expression was significantly correlated with a poor disease-free survival $(p=0.017)$ and disease-specific survival ( $p=0.016)$. Conclusion: P16 expression defined with the new AJCC criteria is useful for detecting lymph node metastasis in NSCLC.
\end{abstract}

This article is freely accessible online.

Correspondence to: Dae Hyun Song, MD, Department of Pathology, Gyeongsang National University School of Medicine, 79 Gangnam-ro, Jinju-si, Gyeongsangnam-do, Republic of Korea. Tel: +82 552143150, Fax: +82 552143174, e-mail: golgy@ hanmail.net

Key Words: Non-small cell, lung cancer, P16 protein.
Lung cancer is one of the most frequently detected malignancies in both men and women and its incidence continues to increase annually. According to the eighth edition of the guidelines by the American Joint Committee on Cancer (AJCC) of the lung, tumor size, penetration into nodes, and metastasis (TNM) are used for tumor staging (1). Late-stage tumors are associated with worse clinical outcomes. Tumor size and location determine the T-stage, which ranges from $1 \mathrm{a}, 1 \mathrm{~b}, 1 \mathrm{c}$, to stage 4 . Depending on the nodal infiltration, lung tumors are staged from $\mathrm{N} 0$ to 3 . Metastasis into other lobes or into the extrathoracic cavity are denoted stages M1a to c. Between each combination or TNM staging system, N2 disease is defined as T-stage 1a, 1b, 1c, 2a, 2b with N-stage 2; T-stage 3, 4 with N-stage 1; T-stage 4 with $\mathrm{N}$-stage 0 . As there is constantly increasing attention among surgeons regarding the management of $\mathrm{N} 2$ disease (2), including whether surgical treatment should be involved or not, early detection of lymph node metastasis in lung cancer needs to be accomplished urgently.

$\mathrm{P} 16$ is a tumor-suppressor gene that controls cell-cycle progression by inhibiting cyclin-dependent kinase (CDK)4/6 and phosphorylation of the retinoblastoma (RB) protein. Loss of P16 allows unregulated cell-cycle progression from $\mathrm{G}_{1}$ - to S-phase. P16 has been studied since it is associated with human-papilloma virus (HPV) infection in causing many types of cancer, including cervical and oropharyngeal. In addition to HPV-related cancer, P16 expression has been usually observed in non-small cell lung cancer (NSCLC), and positive expression was shown to be related to good prognosis in many previous studies (3-6). Recently, the AJCC adopted new criteria for oropharyngeal cancer, which include evaluating P16 status for TNM staging. The expression of P16 was defined as positive when nuclear expression has an intensity of $+2 /+3$ and distribution $\geq 75 \%$ of cancer cells. Although there are clinically utilized methods for detection of HPV in head and neck cancer (7), immunohistochemical staining of P16 is the most costeffective detection approach. In this study, therefore, we 
applied this new cut-off value for P16 expression in NSCLC samples, compared it with old criteria, and evaluated the effect of P16 on TNM staging and N2 disease of patients with NSCLC.

\section{Materials and Methods}

Case selection. Representative hematoxylin and eosin slides from 148 consecutive patients with NSCLC were reviewed by two experienced pathologists. The patients underwent surgery for NSCLC at the Gyeongsang National University Hospital, Jinju, Republic of Korea, between January 2002 and December 2009. Electronic medical records were reviewed and the clinical and pathological data, including age, sex, smoking history, histological type, TNM T-stage, $\mathrm{N}$-stage, M-stage, mean survival, and 5-year survival rate were collected (Table I). The stages of cancer were determined according to the eighth edition of the AJCC guidelines (1).

Tissue microarray and immunohistochemistry. Representative hematoxylin and eosin-stained glass slides containing intratumoral lesions from the 148 NSCLC specimens were selected for analysis. To obtain the tissue sample for staining, a core was obtained from the front of the invasive tumor on each representative paraffin block and transplanted into the recipient tissue microarray (TMA) block. Immunohistochemical staining was performed on 4- $\mu \mathrm{m}$ sections of the TMA block samples. Once attached to glass slides, the sections were deparaffinized, rehydrated, and incubated in 3\% hydrogen peroxide for $10 \mathrm{~min}$ to block endogenous peroxidase activity, which can result in nonspecific background staining. Sections were then heated for $20 \mathrm{~min}$ in $10 \mathrm{mM}$ citrate buffer ( $\mathrm{pH} \mathrm{6.0)}$ in a microwave oven $(700 \mathrm{~W})$. After incubation with Ultra V block (Lab Vision Corporation, Fremont, CA, USA) for $7 \mathrm{~min}$ at room temperature to block background staining, slides were incubated with a primary antibody specific to P16 (1:600 dilution, 705-4793; Ventana, Tucson, AZ, USA) and an ultraview Universal DAB detection kit was used (760-500, Ventana, Tucson, AZ, USA) according to the manufacturer's recommendations for visualization. 3, 3'Diaminobenzidine was used to detect the protein. The sections were then counterstained using hematoxylin.

Evaluation of P16 expression. The immunohistochemical staining pattern of P16 was evaluated for each of 145 cores (three cases could not be evaluated due to the loss of tissue specimen) from the TMA blocks. Distinct membranous or cytoplasmic staining for P16 was considered to represent positivity. P16 expression was evaluated by comparison with type II pneumocytes, normal bronchial epithelial cells, and endothelial cells as positive internal controls. In addition, some lymphocytes without nuclear expression of P16 were assessed as the negative internal control. For the new P16 criteria, the intensity of the stained tumor cells was scored as follows: Unstained: 0, weak: $1+$, moderate: $2+$, and strong: $3+$. The proportion of the stained tumor cells was scored as follows: Unstained: $0,1-25 \%$ : $1+, 25-50 \%: 2+, 50-75 \%: 3+$, and more than $75 \%$ : 4+. The expression of P16 was defined as positive when nuclear expression was $+2 /+3$ intensity and distribution $4+$. We also evaluated P16 expression by two old criteria, suggested by Myong et al. (P16 expression considered negative when fewer than $10 \%$ of cancer cells have distinct nuclear staining) (5) and Yoo et al. (samples considered P16-positive when more than $80 \%$ of tumor
Table I. Clinicopathological characteristics of patients $(n=148)$

\begin{tabular}{|c|c|}
\hline Characteristic & Value \\
\hline \multicolumn{2}{|l|}{ Age, years } \\
\hline Mean (range) & $64.85(31-77)$ \\
\hline \multicolumn{2}{|l|}{ Gender, n (\%) } \\
\hline Male & $125(84.5)$ \\
\hline \multicolumn{2}{|l|}{ Smoking history, $\mathrm{n}(\%)$} \\
\hline Yes & $97(65.5)$ \\
\hline \multicolumn{2}{|l|}{ Histological type, n (\%) } \\
\hline Squamous cell carcinoma & $96(64.9)$ \\
\hline Well-differentiated & 15 \\
\hline Moderately differentiated & 59 \\
\hline Poorly differentiated & 22 \\
\hline Adenocarcinoma & $37(25)$ \\
\hline Acinar & 15 \\
\hline Solid & 6 \\
\hline Papillary & 8 \\
\hline Micropapillary & 3 \\
\hline Lepidic & 3 \\
\hline Mucinous & 2 \\
\hline Large-cell neuroendocrine carcinoma & $8(5.4)$ \\
\hline Other & $7(4.7$ \\
\hline \multicolumn{2}{|l|}{ T-Stage, n (\%) } \\
\hline $1 \mathrm{a}$ & $35(23.6)$ \\
\hline $1 b$ & $48(32.4)$ \\
\hline $2 \mathrm{a}$ & $11(7.4)$ \\
\hline $2 \mathrm{~b}$ & $40(27.0)$ \\
\hline $3 a$ & $4(2.7)$ \\
\hline $3 b$ & $8(5.4)$ \\
\hline 4 & $2(1.4)$ \\
\hline \multicolumn{2}{|l|}{ N-Stage, n (\%) } \\
\hline 0 & $103(69.6)$ \\
\hline 1a & $42(28.4)$ \\
\hline $1 b$ & $3(2.0)$ \\
\hline $1 \mathrm{c}$ & $0(0)$ \\
\hline \multicolumn{2}{|l|}{ M-Stage, n (\%) } \\
\hline 0 & $145(98.0)$ \\
\hline $1 \mathrm{a}$ & $3(2.0)$ \\
\hline $1 b$ & $0(0)$ \\
\hline $1 \mathrm{c}$ & $0(0)$ \\
\hline \multicolumn{2}{|l|}{ Survival } \\
\hline Mean (range), months & $37(0-113)$ \\
\hline 5-Year, n $(\%)$ & $33(22.3)$ \\
\hline
\end{tabular}

cells have either nuclear or cytoplasmic staining patterns) for comparison with the new criteria (6).

Statistical analysis. The relationship between P16 expression and clinicopathological characteristics, including age, sex, smoking history, histological type, T-stage, N-stage, and M-stage, and N2 disease were evaluated using chi-square test. Disease-free (DFS) and disease-specific (DSS) survival were evaluated by multivariate Cox proportional hazard regression model. In addition, DFS and DSS were analyzed by the Kaplan- Meier method with a log-rank test. $p$-Values of less than 0.05 were considered statistically significant. SPSS ver. 24.0 (IBM, Armonk, NY, USA) was used for all statistical analyses. 


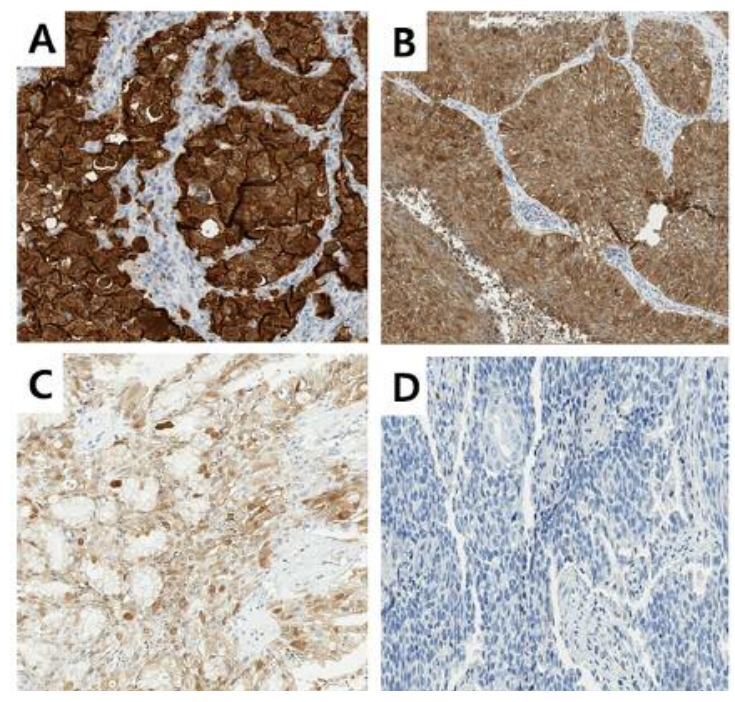

Figure 1. P16 expression in squamous cell carcinoma. $P 16$ positivity showing diffuse nuclear and cytoplasmic expression. $(A: 3+, B: 2+)$. P16 negativity showing non-specific cytoplasmic expression $(C)$ or complete lack of expression $(D)$.

Ethics statement. Informed consent was submitted by all participants when they were enrolled. This study was approved by the Institutional Review Board of the Gyeongsang National University Hospital (GNUH-2019-02-017). All procedures performed in studies involving human participants were in accordance with the ethical standards of the institutional and/or national research committee and with the 1964 Helsinki declaration and its later amendments or comparable ethical standards.

\section{Results}

Patient characteristics. A total of 148 NSCLC cases were enrolled in the study. The clinical and pathological information of NSCLC patients is summarized in Table I. The mean age of the patients was 64.85 years. Amongst them, $125(84.5 \%)$ were male patients and $86(65.2 \%)$ had a history of smoking. The histopathological type of the majority of tumors $(n=96,64.9 \%)$ was squamous cell carcinoma. Most tumors were T-stage $1 \mathrm{a}$ or $1 \mathrm{~b}(\mathrm{n}=83,56 \%)$ and had not spread to lymph nodes $(n=103,69.6 \%)$ nor other sites $(n=145,98.0)$. The mean survival was 37 months and the 5 -year survival rate was $22.3 \%$.

Identification of P16 expression. Ninety-six out of 145 cores were positive for P16 expression. P16 was expressed in the cytoplasm, nucleus, and membrane of NSCLC cells. In both adenocarcinoma and squamous cell carcinoma, there was a wide variety of manifestations, from positive to aberrant to negative expression. In squamous cell carcinoma, P16 positivity was diffusely nuclear and cytoplasmic (Figure 1A:

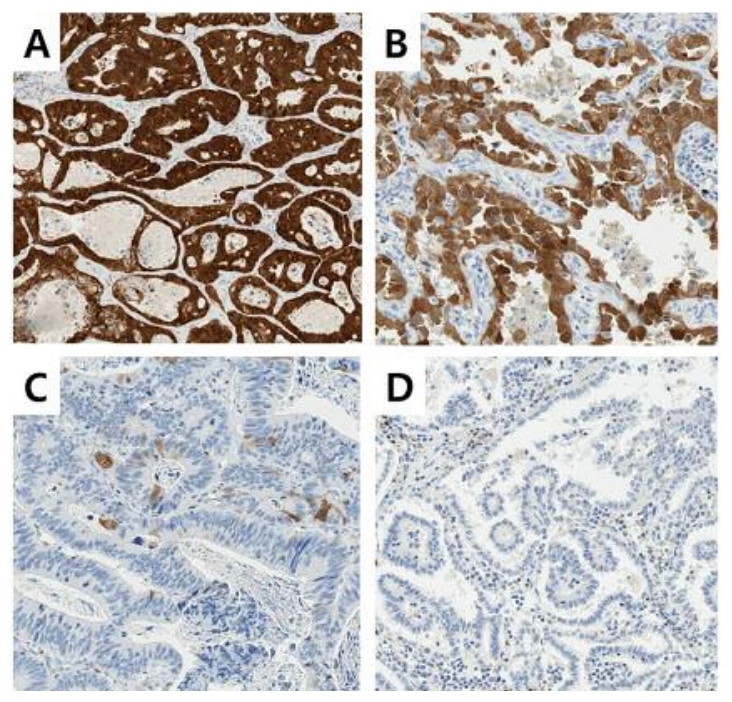

Figure 2. P16 expression in adenocarcinoma. P16 positivity showing diffuse nuclear and cytoplasmic expression $(A: 3+, B: 2+) . P 16$ negativity showing aberrant patchy expression $(C)$ or complete lack of expression $(D)$.

Table II. The correlation between $N$-stage and P16 expression by old and 8th American Joint Committee on Cancer (AJCC) criteria $(N=145)$.

\begin{tabular}{llccc}
\hline & & \multicolumn{2}{c}{ N-Stage, n (\%) } & \\
\cline { 3 - 4 } Criteria & & N16 & N1, 2, 3 & \multirow{2}{*}{ Total } \\
\hline \multirow{2}{*}{ 8th AJCC (1) } & Negative $(0,1+)$ & $61(63.5)$ & $35(36.5)$ & 96 \\
& Positive $(2+, 3+)$ & $40(81.6)$ & $9(18.4)$ & 49 \\
& Total & 101 & 44 & $p=0.025$ \\
Myong et al. (5) & Negative & $53(52.5)$ & $48(47.5)$ & 87 \\
& Positive & $34(77.3)$ & $10(22.7)$ & 49 \\
& Total & 87 & 58 & $p=0.005$ \\
Yoo et al. (6) & Negative & $63(63.6)$ & $36(36.4)$ & 99 \\
& Positive & $38(82.6)$ & $8(17.4)$ & 46 \\
& Total & 101 & 44 & $p=0.021$ \\
\hline
\end{tabular}

3+, Figure 1B: 2+). In contrast, P16-negative samples showed non-specific cytoplasmic expression (Figure 1C) or a complete lack of expression (Figure 1D). In adenocarcinoma, P16 positivity was also diffusely nuclear and cytoplasmic (Figure 2A: 3+, Figure 2B: 2+), whereas P16-negative samples showed aberrant, patchy expression (Figure 2C) or a complete lack of expression (Figure 2D).

Correlation between P16 expression and clinicopathological characteristics. Among the clinical and pathological factors listed previously (age, sex, smoking, histological type, 
in vivo $33: 1885-1892(2019)$

Table III. The correlation between pathological type and P16 expression by old and 8th American Joint Committee on Cancer (AJCC) criteria $(N=145)$.

\begin{tabular}{|c|c|c|c|c|c|c|}
\hline \multirow[b]{2}{*}{ Criteria } & \multirow[b]{2}{*}{ P16 } & \multicolumn{4}{|c|}{ Pathological type, n (\%) } & \multirow[b]{2}{*}{ Total } \\
\hline & & $\begin{array}{l}\text { Squamous cell } \\
\text { carcinoma }\end{array}$ & Adenocarcinoma & $\begin{array}{c}\text { Large-cell } \\
\text { neuroendocrine } \\
\text { carcinoma }\end{array}$ & Other & \\
\hline \multirow[t]{2}{*}{ 8th AJCC criteria (1) } & Negative $(0,1+)$ & $73(76.0)$ & 17 (17.7) & $1(1.0)$ & $5(5.3)$ & 96 \\
\hline & Positive $(2+, 3+)$ & $21(42.9)$ & $20(40.8)$ & $6(12.2)$ & $2(4.1)$ & 49 \\
\hline \multirow[t]{2}{*}{ Myong et al. (5) } & Negative & $68(78.2)$ & $13(14.9)$ & $1(1.1)$ & $5(5.7)$ & 87 \\
\hline & Positive & $26(44.8)$ & $24(41.4)$ & $6(10.3)$ & $2(1.4)$ & 58 \\
\hline \multirow[t]{2}{*}{ Yoo et al. (6) } & Negative & $71(71.7)$ & $20(20.2)$ & $2(2.0)$ & $6(6.1)$ & 99 \\
\hline & Positive & $23(50.0)$ & $17(37.0)$ & $5(10.9)$ & $1(14.3)$ & 46 \\
\hline Total & & 94 & 37 & 7 & 7 & $p=0.008$ \\
\hline
\end{tabular}

pathological T-stage, N-stage, and M-stage), N0 stage was statistically significantly associated with $\mathrm{P} 16$ positivity when determined with both the new and old P16 criteria. (8th AJCC criteria: $p=0.025$; Myong et al : $p=0.005$; Yoo et al.: $p=0.021$, Table II). In addition, squamous cell carcinoma was statistically significantly associated with P16 negativity by both old and new evaluation motheds (8th AJCC criteria: $p<0.001$; Myong et al: $p<0.001$; Yoo et al.: $p=0.008$, Table III). Of the 148 patients with NSCLC, there were two with $\mathrm{N} 2$ disease (stage IIIA). Both of them had a recurrence and one died. Samples from both patients had were negative for P16 expression.

Correlation between P16 expression and survival data. To confirm P16 expression as an independent prognostic marker, univariate and multivariate Cox proportional analyses were performed. NSCLC with negative P16 expression demonstrated poor DFS (hazard ratio $=1.937,95 \%$ confidence interval $=1.069-3.183, p=0.028)$ and poor DSS (hazard ratio $=1.886,95 \%$ confidence interval $=1.018-3.493$, $p=0.044$ ) in multivariate analysis (Table IV). The KaplanMeier survival curve confirmed that advanced TNM stage and negative P16 expression were significantly associated with poor DFS $(p=0.017)$ and poor DSS $(p=0.016$, Figure $3)$. In contrast, the DSS and DFS data demonstrated no significant results when the old P16 criteria were applied (Myong et al: $p=0.109$ for DFS, $p=0.067$ for DSS; Yoo et $a l .: p=0.133$ for DFS, and $p=0.119$ for DSS).

Comparison between the old and new P16 criteria. There were 18 cases which demonstrated different P16 status when the old and new P16 criteria were applied. All were P16positive using Myong et al.'s criteria, whereas the new criteria and those of Yoo et al. tended to show the opposite results (Table V). Representative microscopic findings of
P16 expression which showed contradictory results when different criteria were applied are shown in Figure 4.

\section{Discussion}

Following HPV infection, E7 and E6 suppress the RB1 and TP53 tumor-suppressor genes, respectively, allowing unrestricted replication of cancer cells. When HPV-related carcinogenesis is induced, along with E7 and E6, P16 is also overexpressed. HPV16 E7 simultaneously neutralizes the P16-induced senescence response and phosphorylation of pRB, allowing HPV16 E7-expressing cells to continuously proliferate, maintaining high levels of P16 (8-10). In head and neck cancer, mainly of the oropharynx and sinonasal cavity, P16 positivity correlates well with high risk-HPV infection (11).

In contrast, some studies argued that the relationship between high-risk HPV infection and P16 is not relevant in lung cancer $(12,13)$. Rebert et al. identified that out of 211 primary lung carcinomas, all were negative for high-risk HPV. The remaining high-risk HPV-positive equivocal lung carcinomas had a history of high risk-HPV-associated diseases, as with tonsillar and cervical carcinomas (12). Chang et al. demonstrated that P16 was positive in 28 out of 196 patients with lung cancer, however, HPV DNA and RNA in situ hybridization did not detect HPV infection in any case of primary lung cancer (13). Lung cancer is thus known to be an HPV-negative cancer, and P16 expression in the lung increases regardless of HPV E7. Oncogenic stresses other than high-risk HPV infection lead to KDM6B histone methylation, resulting in repression of the P16 tumorsuppressor gene to inhibit CDK4/6 activity. CDK4/6 inhibition subsequently leads to accumulation of the hypophosphorylated RB1 tumor suppressor, leading to G1 cellcycle arrest (7). The higher the P16 expression, the greater 
Table IV. Cox proportional hazards regression model of disease-free and disease-specific survival for patients with non-small cell lung cancer $(n=145)$.

\begin{tabular}{|c|c|c|c|c|c|c|c|c|c|c|c|c|}
\hline \multirow[b]{3}{*}{ Variable } & \multicolumn{6}{|c|}{ Disease-free survival } & \multicolumn{6}{|c|}{ Disease-specific survival } \\
\hline & \multicolumn{3}{|c|}{ Univariate } & \multicolumn{3}{|c|}{ Multivariate } & \multicolumn{3}{|c|}{ Univariate } & \multicolumn{3}{|c|}{ Multivariate } \\
\hline & HR & $95 \% \mathrm{CI}$ & $p$-Value & HR & $95 \% \mathrm{CI}$ & $p$-Value & $\mathrm{HR}$ & $95 \% \mathrm{CI}$ & $p$-Value & HR & $95 \% \mathrm{CI}$ & $p$-Value \\
\hline \multicolumn{13}{|l|}{ Age } \\
\hline$<65 v s . \geq 65$ Years & 1.308 & $0.811-2.110$ & 0.265 & & & & 1.230 & $0.738-2.051$ & 0.427 & & & \\
\hline \multicolumn{13}{|l|}{ Gender } \\
\hline Female $v s$. male & 0.519 & $0.238-1.132$ & 0.099 & & & & 0.316 & $0.115-0.871$ & 0.026 & 0.354 & $0.128-0.982$ & 0.046 \\
\hline \multicolumn{13}{|l|}{ Smoking } \\
\hline $\begin{array}{l}\text { Non-smoker } v s . \text { smoker } \\
\text { Surgery }\end{array}$ & 0.844 & \multicolumn{11}{|c|}{ Surgery } \\
\hline $\mathrm{W}, \mathrm{Sg}, \mathrm{L} v s . \mathrm{B}, \mathrm{P}$ & 1.594 & $0.854-2.973$ & 0.143 & & & & 1.494 & $0.759-2.944$ & 0.246 & & & \\
\hline \multicolumn{13}{|l|}{ Pathology } \\
\hline $\mathrm{A}, \mathrm{L}, \mathrm{O} v s . \mathrm{Sq}$ & 1.854 & $0.987-3.480$ & 0.055 & & & & 2.340 & $1.101-4.971$ & 0.027 & & & \\
\hline \multicolumn{13}{|l|}{ T-Stage* } \\
\hline 1 vs. $2,3,4$ & 1.866 & $1.136-3.066$ & 0.014 & 1.778 & $1.081-2.922$ & 0.023 & 1.591 & $0.940-2.693$ & 0.084 & & & \\
\hline \multicolumn{13}{|l|}{ N-Stage* } \\
\hline 0 vs. $1,2,3$ & 1.249 & $0.765-2.040$ & 0.374 & & & & 1.370 & $0.814-2.396$ & 0.236 & & & \\
\hline \multicolumn{13}{|l|}{ P16: AJCC* } \\
\hline Positive vs. negative & 1.913 & $1.109-3.297$ & 0.020 & 1.937 & $1.069-3.183$ & 0.028 & 2.083 & $1.128-3.846$ & 0.019 & 1.886 & $1.018-3.493$ & 0.044 \\
\hline \multicolumn{13}{|l|}{ Myong et al. (5) } \\
\hline Positive $v s$. negative & 1.501 & $0.914-2.466$ & 0.109 & & & & 1.673 & $0.965-2.902$ & 0.067 & & & \\
\hline Yoo et al. (6) & & & & & & & & & & & & \\
\hline Positive $v s$. negative & 1.488 & $0.872-2.538$ & 0.145 & & & & 1.609 & $0.885-2.924$ & 0.119 & & & \\
\hline
\end{tabular}

HR: Hazard ratio, CI: confidence interval; W: wedge resection, Sg: segmentectomy; L: lobectomy; B: bi-lobectomy; P: pneumonectomy; Sq: squamous cell carcinoma; A: adenocarcinoma; LC: large-cell neuroendocrine carcinoma; O: other. *8th American Joint Committee on Cancer (AJCC) (1).

Table V. The correlation of P16 status and survival data regarding old and 8th American Joint Committee on Cancer (AJCC) criteria for P16 expression $(n=18)$.

\begin{tabular}{|c|c|c|c|c|c|c|c|c|c|}
\hline \multirow{2}{*}{$\begin{array}{l}\text { Gender/age, } \\
\text { years }\end{array}$} & \multicolumn{8}{|c|}{ P16 status } & \multirow[b]{2}{*}{ Recurrence } \\
\hline & T-Stage & N-Stage & Death & AJCC & Myong et al. (5) & Yoo et al. (6) & DFS (months) & DSS (months) & \\
\hline $\mathrm{M} / 67$ & $3 b$ & 0 & Yes & Negative & Positive & Positive & 8 & 13 & Yes \\
\hline $\mathrm{M} / 72$ & $3 b$ & 1 & Yes & Negative & Positive & Positive & 4 & 7 & Yes \\
\hline $\mathrm{M} / 71$ & 4 & 1 & Yes & Positive & Positive & Negative & 9 & 9 & Yes \\
\hline $\mathrm{M} / 72$ & $3 b$ & 0 & No & Positive & Positive & Negative & 93 & 93 & No \\
\hline $\mathrm{M} / 64$ & 4 & 0 & Yes & Positive & Positive & Negative & 1 & 1 & Yes \\
\hline $\mathrm{M} / 71$ & $2 b$ & 0 & Yes & Positive & Positive & Negative & 24 & 24 & Yes \\
\hline $\mathrm{M} / 52$ & $3 b$ & 0 & No & Positive & Positive & Negative & 72 & 72 & No \\
\hline $\mathrm{M} / 68$ & $2 \mathrm{a}$ & 0 & No & Negative & Positive & Negative & 0 & 78 & Yes \\
\hline $\mathrm{M} / 64$ & $2 \mathrm{a}$ & 0 & No & Negative & Positive & Negative & 57 & 57 & No \\
\hline $\mathrm{M} / 65$ & $3 b$ & 1 & Yes & Negative & Positive & Positive & 14 & 28 & Yes \\
\hline $\mathrm{M} / 57$ & $2 \mathrm{a}$ & 0 & No & Positive & Positive & Negative & 54 & 54 & No \\
\hline $\mathrm{M} / 58$ & $3 b$ & 1 & No & Positive & Positive & Negative & 52 & 52 & No \\
\hline $\mathrm{F} / 74$ & $3 b$ & 1 & No & Positive & Positive & Negative & 40 & 40 & No \\
\hline $\mathrm{F} / 77$ & $3 b$ & 0 & No & Positive & Positive & Negative & 33 & 33 & No \\
\hline $\mathrm{M} / 59$ & $3 a$ & 0 & Yes & Negative & Positive & Positive & 29 & 29 & Yes \\
\hline $\mathrm{M} / 71$ & $3 b$ & 0 & No & Negative & Positive & Positive & 30 & 30 & No \\
\hline $\mathrm{M} / 66$ & $1 b$ & 0 & No & Negative & Positive & Positive & 30 & 30 & No \\
\hline $\mathrm{M} / 62$ & 4 & 0 & Yes & Negative & Positive & Positive & 2 & 11 & Yes \\
\hline
\end{tabular}

DFS: Disease-free survival, DSS: disease-specific survival. 

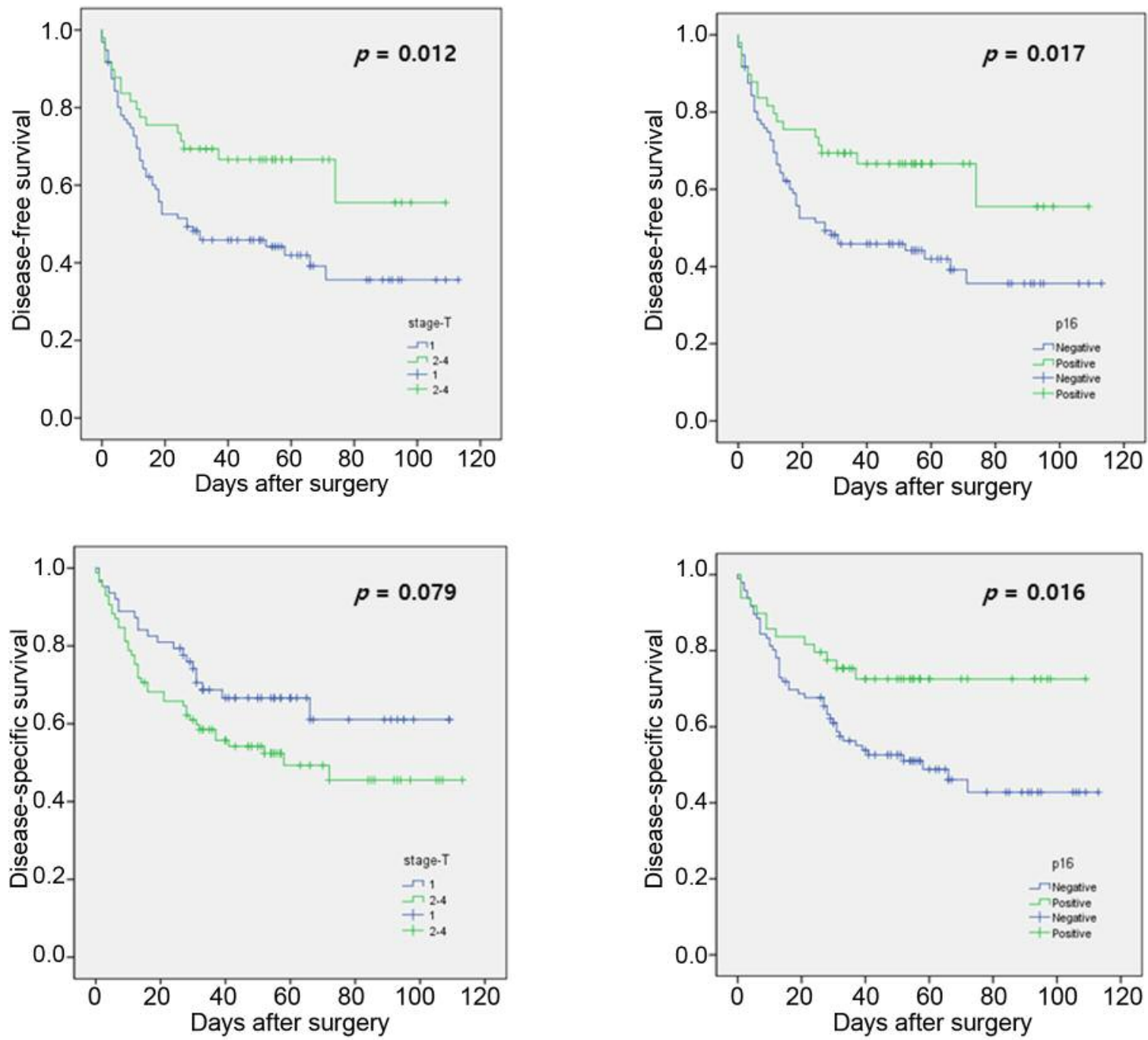

Figure 3. Kaplan-Meier curves showing statistically significant relationship of TMN stage and P16 expression disease-free (A and B, respectively) and disease-specific ( $C$ and $D$, respectively) expression in non-small cell lung cancer.

the effect on cell-cycle arrest; therefore, lung cancer progresses when it is P16-negative.

In this study, we explored the relevance of P16 expression in predicting lymph node metastasis in NSCLC. This has been previously reported to have a statistically significant relationship (6). However, we applied the newly defined criteria for P16 positivity of the eighth AJCC classification for head and neck cancer (nuclear expression with $+2 /+3$ intensity and $4+$ distribution) on NSCLC. N-Stage was statistically significantly correlated with P16 positivity even when we applied the new criteria $(p=0.025)$. In addition, there was a strong association between the histological type and P16 expression $(p<0.001)$. In both squamous cell carcinoma and adenocarcinoma, there was a wide variety of manifestations of P16 expression, from positive to aberrant to negative. Finally, the Kaplan-Meier survival analysis confirmed that advanced TNM stage and P16 negativity were both significantly correlated with poor DFS $(p=0.017)$ and poor DSS $(p=0.016)$.

Even though there have been many attempts to predict the prognosis of lung cancer in Asian people with P16, there has been little success. Previously, Taga et al. (Japanese) (14), Cheng et al. (Chinese) (15), and Mohamedet et al. (Japanese) (16) applied the P16-positive criteria of nuclear expression with more than $10 \%$ distribution in NSCLC and obtained results showing the prognostic significance of P16 in NSCLC in univariate or multivariate analysis. Since it has been revealed that the characteristic genomic patterns of lung cancer might differ according to ethnic group, for our study, we concentrated on the data of Korean patients. We evaluated 


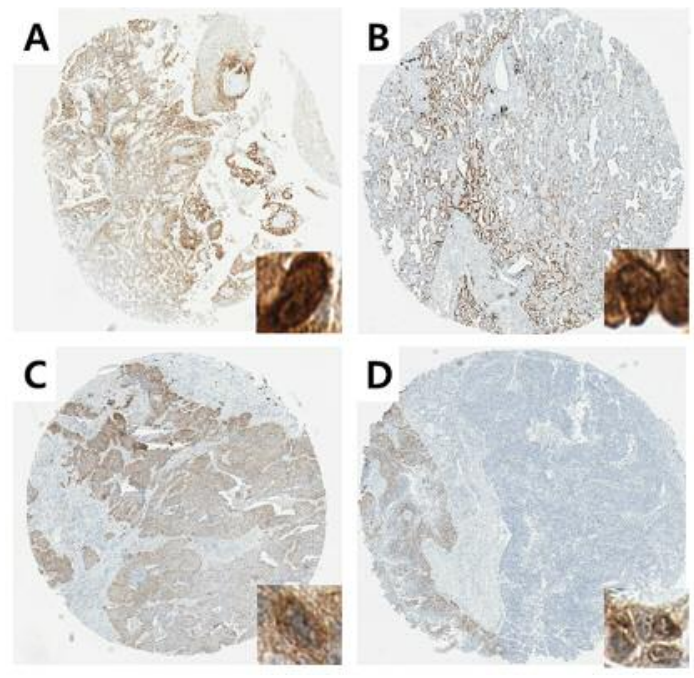

Figure 4. Controversial P16 expression using different P16 criteria. A and B: A sample defined as having positive P16 expression according to eighth American Joint Committee on Cancer (AJCC) criteria (1) and Myong et al.'s (5) criteria but negative by Yoo et al.'s. (6) criteria. C: A sample defined as having negative P16 expression by applying eighth AJCC criteria but positive by Myong et al. and Yoo et al.'s criteria. D: A sample defined as having negative P16 expression by eighth AJCC and Yoo et al.'s criteria but positive by Myong et al.'s criteria (tissue microarray cores: $\times 20$; inset: $\times 400$ ).

three different criteria for P16 evaluation, which were applied to the NSCLC tissue of Korean patients. To the best of our knowledge, this is the first study to evaluate the new P16 criteria, developed by the AJCC for head and neck cancer in the lower airway, in patients with NSCLC from South Korea. Regarding patients with NSCLC from South Korea, Myung et al. defined samples as P16-negative when fewer than $10 \%$ of cancer cells had distinct nuclear staining (5), whereas Yoo et al. suggested that samples should be considered P16-positive when more than $80 \%$ of tumor cells were stained in either nuclear or cytoplasmic patterns (6). Therefore, we compared the new P16 criteria with the old criteria suggested by Myong et al. (5) and Yoo et al. (6). Lymph node metastasis was statistically significantly associated with lack of P16 expression using the older criteria (Myong et al.: $p=0.005$; Yoo et al.: $p=0.021$ ). In contrast, the DSS and DFS data were not significantly correlated with P16 expression by these criteria (Myong et al: $p=0.109$ in DFS, $p=0.067$ in DSS; Yoo et al:: $p=0.133$ in DFS, and $p=0.119$ in DSS).

Despite having no association with HPV infection, P16 is a cost-effective marker for evaluating patients with NSCLC with lymph node metastasis. We suggest that by taking advantage of the P16 expression state ahead of operable N2 disease, clinicians will be able to explore more options for treating aggressive NSCLC cases. In addition, our data strongly suggest that the new criteria of P16 are useful for managing the clinical course and predicting prognosis in patients with NSCLC since P16 expression was statistically significantly related to survival, both DFS and DSS. One limitation of this study was that unlike previous reports of the expression of P16 being related to smoking $(18,19)$, we did not find a connection between smoking and P16.

In this investigation, we used immunohistochemical staining of TMA blocks and statistical analysis to evaluate the predictive role of P16 in NSCLC and demonstrated that negative P16 expression was significantly associated with NSCLC with lymph node metastasis, and poor DFS and DSS. Targeted therapy for the oncogenic mechanism of P16 action for regulation of tumor growth and metastasis might be useful. To conclude, applying the new criteria of P16 expression is useful for detecting lymph node metastasis and monitoring the clinical course of patients with NSCLC.

\section{Conflicts of Interest}

The Authors declare that they have no conflicts of interest in regard to this study.

\section{Author's Contributions}

Conceptualization: Song DH, An HJ; Methodology: Song DH, An HJ; Software: An HJ; Validation: Song DH; Formal analysis: Song DH, Koh HM; Investigation: Koh HM, An HJ; Data curation: Koh $\mathrm{HM}$, An HJ; Writing, original draft preparation: An HJ; Writing, review and editing: Song DH, Koh HM; Approval of final manuscript: All Authors.

\section{Acknowledgements}

This research did not receive any specific grant from funding agencies in the public, commercial, or not-for-profit sectors.

\section{References}

1 Amin MB, Edge SB and Greene FL: AJCC (American Joint Committee on Cancer) Cancer Staging Manual, Eighth Edition. Amin MB, Edge SB and Greene FL (eds.). Chicago, Springer, 2017.

2 Rocco G, Nason K, Brunelli A, Varela G, Waddell T and Jones DR: Management of stage IIIA (N2) non-small-cell lung cancer: A transatlantic perspective Eur J Cardiothorac Surg 49: 10251027, 2016. PMID: 26985072. DOI: 10.1093/ejcts/ezw040

3 Sterlacci W, Tzankov A, Veits L, Zelger B, Bihl MP, Foerster A, Augustin F, Fiegl M and Savic S: A comprehensive analysis of p16 Expression, gene status and promotor hypermethylation in surgically resected non-small cell lung carcinomas $\mathrm{J}$ Thorac Oncol 6: 1649-1657, 2011. PMID: 21857254. DOI: 10.1097/ JTO.0b013e3182295745

4 Tong J1, Sun X, Cheng H, Zhao D, Ma J, Zhen Q, Cao Y, Zhu $\mathrm{H}$ and Bai J: Expression of P16 in non-small cell lung cancer and its prognostic significance: A meta-analysis of published literatures Lung cancer 74: 155-163, 2011. PMID: 21621871. DOI: 10.1016/j.lungcan.2011.04.019 
5 Myong NH: Cyclin D1 overexpression, p16 loss and pRb inactivation play a key role in pulmonary carcinogenesis and have a prognostic implication for the long-term survival in nonsmall cell lung carcinoma patients. Cancer Res Treat 40: 45-52, 2008. PMID: 19688048. DOI: 10.4143/crt.2008.40.2.45

6 Yoo J, Jung JH, Lee MA, Seo KJ, Shim BY, Kim SH, Cho DG, Ahn MI, Kim $\mathrm{CH}$, Cho KD, Kang SJ and Kim HK: Immunohistochemical analysis of non-small cell lung cancer: correlation with clinical parameters and prognosis. J Korean Med Sci 22: 318-325, 2007. PMID: 17449943. DOI: 10.3346/ jkms.2007.22.2.318

7 Schlecht NF, Brandwein-Gensler M, Nuovo GJ, Li M, Dunne A, Kawachi N, Smith RV, Burk RD and Prystowsky MB: A comparison of clinically utilized human papillomavirus detection methods in head and neck cancer Mod Pathol 24: 1295-1305, 2011. PMID: 21572401. DOI: 10.1038/modpathol.2011.91

8 Munger K and Jones DL: Human papillomavirus carcinogenesis: an identity crisis in the retinoblastoma tumor suppressor pathway. J Virol 89: 4708-4711, 2015. PMID: 25673729. DOI: 10.1128/JVI.03486-14

9 McLaughlin-Drubin M, Crum CP and Munger K: Human papillomavirus E7 oncoprotein induces KDM6A and KDM6B histone demethylase expression and causes epigenetic reprogramming. Proc Natl Acad Sci USA 108: 2130-2135, 2011. PMID: 21245294. DOI: 10.1073/pnas.1009933108

10 McLaughlin-Drubin ME, Park D and Munger K: Tumor suppressor p16INK4A is necessary for survival of cervical carcinoma cell lines. Proc Natl Acad Sci USA 110: 1617516180, 2013. PMID: 24046371. DOI: 10.1073/pnas.1310432110

11 Doxtader EE and Katzenstein AL: The relationship between p16 expression and high-risk human papillomavirus infection in squamous cell carcinoma from sites other than uterine cervix: a study of 137 cases. Hum Pathol 43: 327-332, 2012. PMID: 21840041. DOI: 10.1016/j.humpath.2011.05.010

12 van Boerdonk RA, Daniels JM, Bloemena E, Krijgsman O, Steenbergen RD, Brakenhoff RH, Grunberg K, Ylstra B, Meijer CJ, Smit EF, Snijders PJ and Heideman DA: High-risk human papillomavirus-positve lung cancer Molecular evidence for a pattern of pulmonary metastasis. J Thorac Oncol 8: 711-718, 2013. PMID: 23571474. DOI: 10.1097/JTO.0b013e3182897c14

13 Chang SY, Keeney M, Law M, Donovan J, Aubry MC and Garcia J: Detection of human papillomavirus in non-small cell carcinoma of the lung. Hum Pathol 46: 1592-1597, 2015. PMID: 26342243. DOI: 10.1016/j.humpath.2015.07.012
14 Taga S, Osaki T, Ohgami A, Imoto H, Yoshimatsu T, Yoshino I, Yano K, Nakanishi R, Ichiyoshi Y and Yasumoto K: Prognostic value of the immunohistochemical detection of p16INK4 expression in nonsmall cell lung carcinoma. Cancer 80: 389-395, 1997. PMID: 9241072. DOI: 10.1002/(sici)1097-0142(19970801)80:3<389::aidcncr6>3.0.co;2-n

15 Cheng YL, Lee SC, Harn HJ, Chen CJ, Chang YC, Chen JC and $\mathrm{Yu}$ CP: Prognostic prediction of the immunohistochemical expression of p53 and p16 in resected non-small cell lung cancer. Eur J Cardiothorac Surg 23: 221-228, 2003. PMID: 12559346. DOI: 10.1016/s1010-7940(02)00749-2

16 Mohamed S, Yasufuku K, Hiroshima K, Nakajima T, Yoshida S, Suzuki M, Sekine Y, Shibuya K, Iizasa T, Farouk A and Fujisawa T: Prognostic implications of cell cycle-related proteins in primary resectable pathologic N2 non-small cell lung cancer. Cancer 109: 2506-2514, 2007. PMID: 17487846. DOI: 10.1002/ cncr.22651

17 Beitler JJ, Switchenko JM, Dignam JJ, McDonald MW, Saba NF, Shin DM, Magliocca KR, Cassidy RJ, El-Deiry MW, Patel MR, Steuer CE, Xiao C, Hudgins PA, Aiken AH, Curran WJ Jr. and Le QT: Smoking, age, nodal disease, T-stage, p16 status and risk of distant metastases in patients with squamous cell cancer of the oropharynx. Cancer 125(5): 704-711, 2019. PMID: 30548235. DOI: $10.1002 /$ cncr.31820

18 Hong YS, Roh MS, Kim NY, Lee HJ, Kim HK, Lee KE, Kwak JY and Kim JY: Hypermethylation of P16 ${ }^{\text {INK4a }}$ in Korean nonsmall cell lung cancer patients. J Korean Med Sci 22: S32-37, 2007. PMID: 17923752. DOI: 10.3346/jkms.2007.22.S.S32

19 Zhang B, Zhu W, Yang P, Liu T, Jiang M, He ZN, Zhang SX, Chen WQ and Chen W: Cigarette smoking and P16 INK4A gene promotor hypermethylation in non-small cell lung carcinoma patients: A meta-analysis. PLOS One 206: e28882, 2011. PMID: 22174919. DOI: 10.1371/journal.pone.0028882 